\title{
Politik Hukum Sistem Pemilu Legislatif dan Presiden Tahun 2009 dan 2014 dalam Putusan Mahkamah Konstitusi
}

\author{
Bagus Anwar Hidayatulloh \\ Program Magister Hukum FH UII \\ Jl. Cik Di Tiro No. 1 Yogyakarta \\ bagusanwar.responsif@gmail.com
}

\begin{abstract}
The election in Indonesia is regulated by the Electoral Law which is always changing. One of the reasons was due to a judicial review at the Constitutional Court, for example related to the Election Law in 2009 and 2014. As a result, there arose several problems, first, how is the political direction of the legal system of legislative and presidential elections in 2009 and 2014 related to the Constitutional Court's decision? Secondly, what are the political implications of the law on the Constitutional Court's ruling against the system of legislative and presidential elections in 2009 and 2014? This study will examine the subject of the matters through the juridical-normative approach and case approach. The study concluded, first, the legal political system of elections in 2009 and 2014 in the decisions of the Constitutional Court is more about the maintenance to achieve the substantive democracy, while the democracy procedural got less attention. Thus, some Constitutional Court's decisions ignore the nature of procedural democracy in order to obtain substantial democracy. Secondly, the Constitutional Court's decisions raise several direct and indirect implications.
\end{abstract}

Keywords: Politics, law, electoral system, verdict, the Constitutional Court.

\begin{abstract}
Abstrak
Pemilu di Indonesia diatur dengan Undang-Undang Pemilu yang selalu berubah-ubah, salah satunya dikarenakan adanya judicial review di Mahkamah Konstitusi, misalnya terkait UU Pemilu 2009 dan 2014. Karena itu timbul suatu permasalahan, pertama, bagaimana arah politik hukum sistem pemilu legislatif dan presiden tahun 2009 dan 2014 dalam putusan Mahkamah Konstitusi? Kedua, apakah implikasi politik hukum atas putusan Mahkamah Konstitusi terhadap sistem pemilu legislatif dan presiden tahun 2009 dan 2014? Penelitian ini akan mengkaji pokok permasalahan melalui pendekatan yuridis-normatif dan pendekatan kasus. Hasil penelitian menyimpulkan, pertama, politik hukum sistem pemilu tahun 2009 dan 2014 dalam putusan-putusan Mahkamah Konstitusi lebih kepada penegakan untuk mencapai demokrasi substansial, sedangkan demokrasi proseduralnya kurang begitu diperhatikan. Sehingga beberapa putusan MK tersebut mengabaikan sifat demokrasi prosedural guna mendapatkan demokrasi substansialnya. Kedua, Putusan MK menimbulkan beberapa implikasi baik secara langsung maupun tidak langsung.
\end{abstract}

Kata Kunci : Politik hukum, sistem pemilu, putusan, mahkamah konstitusi 


\section{Pendahuluan}

Perubahan UUD 1945 menjadi tonggak yang tak terpisahkan dari Reformasi. Bagi pendukung perubahan, apa yang dilakukan MPR selama periode 1999-2002 merupakan lompatan besar. Reformasi berjalan di alur yang benar karena tetap mempertahankan Pancasila sebagai dasar negara. ${ }^{1}$ Secara yuridis negara Indonesia telah melangsungkan 4 kali Pemilu pasca reformasi yang menandakan ada peraturan yang pasti berubah, dibandingkan dengan era orde baru. Pelaksanaan pemilu tidak terlepas dari perundang-undangan yang berlaku. Pemilu 2009 mengacu pada 4 undang-undang yang berkaitan dengan penyelenggaraan pemilu. Sedangkan pemilu terakhir yang diselenggarakan adalah pemilu 2014. Pemilu tersebut mengacu pada 4 undang-undang yang berkaitan dengan penyelenggaraan pemilu.

Menurut Mahfud MD, hukum adalah produk politik, sehingga ketika membahas politik hukum cenderung mendiskripsikan pengaruh politik terhadap hukum atau pengaruh sistem politik terhadap pembangunan hukum. Politik hukum juga mencakup pengertian tentang bagaimana politik mempengaruhi hukum dengan cara melihat konfigurasi kekuatan yang ada di belakang pembuatan dan penegakan hukum. ${ }^{2}$ Lahirnya undang-undang pemilu 2009 dan 2014 tersebut tidak terlepas dari konfigurasi politik. Pelaksanaan pemilu 2009 dan 2014 merupakan pemilu yang bertepatan dengan Era Kabinet Indonesia Bersatu. Kedua pemilu tersebut memiliki politik hukum dan konfigurasi yang tercermin dalam sistem dan pelaksanaannya. Konfigurasi kekuatan dan kepentingan dalam badan pembuat undang-undang dan intervensi-intervensi dari luar tidak dapat diabaikan dalam pembentukan undang-undang. Intervensi tersebut dilakukan terutama oleh golongan yang memiliki kekuasaan dan kekuatan, baik secara sosial, politik maupun ekonomi. ${ }^{3}$

1 Udiyo Basuki, “Quo Vadis UUD 1945: Refleksi 65 Tahun Indonesia Berkonstitusi”, dalam Jurnal Supremasi Hukum, Vol.1 No.1, Juni 2012, hlm. 18.

2 Moh. Mahfud MD, Politik. Hukum di Indonesia, PT Rajagrafindo Persada, Jakarta, 2009, hlm. 4. Konfigurasi politik, menurut Moh. Mahfud MD mengandung arti sebagai susunan atau konstelasi kekuatan politik yang secara dikotomis dibagi atas dua konsep yang bertentangan secara diametral, yaitu konfigurasi politik demokratis dan konfigurasi politik otoriter.

3 Jazuni, Legislasi Hukum Islam di Indonesia, Citra Aditya Bakti, Bandung, 2005, hlm. 9-10. 
Dalam perkembangannya, undang-undang yang telah lahir untuk menghundle pelaksanaan pemilu, mengalami gejolak politik akibat beberapa pihak merasa tidak puas terhadap klausula di beberapa pasal terkait undang-undang tersebut. Pemilu di Indonesia diatur dengan undang-undang pemilu yang selalu berubah-ubah karena kebutuhan perbaikan kualitas, karena pengaruh konfigurasi politik dan karena perubahan demografi-kependudukan dan peta pemerintahan. ${ }^{4}$ Maka dari itu, produk hukum pemilu tersebut mengalami pasang surut perubahan isi substansi pasalnya. Salah satunya dikarenakan adanya judicial review di Mahkamah Konstitusi. Terdapat beberapa undang-undang yang telah diuji di Mahkamah Konstitusi terkait Pemilu 2009 dan 2014. Tetapi tidak semua permohonan gugatan ke Mahkamah Konstitusi diterima, ada yang ditolak dan ada pula yang dikabulkan. Putusan Mahkamah Konstitusi yang dikabulkan menjadi produk hukum baru yang diterapkan pada Pemilu 2009 dan 2014. Putusan Mahkamah Kontitusi perihal undang-undang yang berkaitan dengan Pemilu 2009 diantaranya: 1. putusan Mahkamah Konstitusi terhadap uji materi UU No. 42 Tahun 2008 tentang Pemilihan Umum Presiden dan Wakil Presiden untuk Pasal 188 ayat (2), (3), (5), Pasal 228, Pasal 255 terkait dengan larangan pengumuman perhitungan cepat pada pemilu presiden dan wakil presiden pada saat hari dilaksanakannya pilpres; 2. putusan Mahkamah Konstitusi terhadap uji materi UU No. 10 Tahun 2008 tentang tentang Pemilihan Umum Anggota Dewan Perwakilan Rakyat, Dewan Perwakilan Daerah dan Dewan Perwakilan Rakyat Daerah Pasal 214 huruf a, b, c, d, e, terkait mengenai penetapan caleg untuk pemilu yang akan ditentukan dengan sistem suara terbanyak; 3. putusan Mahkamah Konstitusi terhadap uji materi UU No. 42 Tahun 2008 tentang Pemilihan Presiden dan Wakil Presiden Terkait dengan Penggunaan KTP dan Paspor dalam Pemilihan Presiden dan Wakil Presiden.

Adapun Putusan Mahkamah Konstitusi yang berkaitan dengan Pemilu 2014 diantaranya: 1. putusan Mahkamah Konstitusi terhadap uji materi UU No. 8 Tahun 2012 tentang Pemilihan Umum Anggota Dewan Perwakilan Rakyat, Dewan Perwakilan Daerah, dan Dewan Perwakilan Rakyat Daerah untuk Pasal 8 ayat (1) dan (2), Pasal 17 ayat (1), Pasal 208, serta Pasal 209 ayat (1) dan (2)

\footnotetext{
${ }^{4}$ Jenedjri M. Gaffar, Politik Hukum Pemilu, Konstitusi Press, Jakarta, 2012, hlm. xiv.
} 
mengenai parliamentary threshold atau ambang batas parlemen sebesar 3,5 persen dalam UU Pemilu yang digunakan untuk menentukan anggota DPR, DPRD Provinsi, DPRD kota dan kabupaten; 2. putusan Mahkamah Konstitusi terhadap uji materi UU No. 8 Tahun 2012 tentang Pemilihan Umum Anggota Dewan Perwakilan Rakyat, Dewan Perwakilan Daerah, dan Dewan Perwakilan Rakyat Daerah untuk Pasal 247 ayat (2), ayat (5), ayat (6), Pasal 291 dan Pasal 317 ayat (1), ayat (2) yang berkaitan mencabut larangan pengumuman hasil survei atau jajak pendapat saat masa tenang pemilu; 3. putusan Mahkamah Konstitusi terhadap uji materi UU No. 42 Tahun 2008 tentang Pemilihan Presiden dan Wakil Presiden (UU Pilpres) untuk Pasal 3 ayat (4), Pasal 9, Pasal 14 ayat (2), dan Pasal 112 mengenai pemilu dilaksanakan secara serentak dan presidential threshold dapat dihapuskan tetapi untuk presidential threshold tidak dikabulkan; 4. putusan Mahkamah Konstitusi terhadap uji materi UU No. 42 Tahun 2008 tentang Pemilihan Presiden dan Wakil Presiden Pasal 159 ayat (1) berkaitan dengan pemilihan umum satu putaran.

Peneliti mengambil kajian perihal politik hukum sistem pemilu dalam putusan Mahkamah Konstitusi 2009 dan 2014 karena dinilai merupakan tonggak baru kematangan pada proses transisi antara sebelum dan pasca adanya Mahkamah Konstitusi. Peneliti menganggap permasalahan ini menarik untuk dikaji, karena putusan Mahkamah Konstitusi berimplikasi pada desain politik hukum sistem pemilu pada pemilu legislatif dan presiden di 2009 dan 2014.

\section{Rumusan Masalah}

Dari latar belakang masalah di atas, rumusan masalah yang hendak dikaji dalam penelitian ini adalah: pertama, bagaimana arah politik hukum sistem pemilu legislatif dan presiden 2009 dan 2014 dalam putusan Mahkamah Konstitusi? Kedua, apa implikasi politik hukum atas putusan Mahkamah Konstitusi terhadap sistem pemilu legislatif dan presiden 2009 dan 2014 ? 


\section{Tujuan Penelitian}

Penelitian ini bertujuan untuk mengetahui, pertama, arah politik hukum sistem pemilu legislatif dan presiden 2009 dan 2014 dalam putusan Mahkamah Konstitusi. Kedua, implikasi politik hukum atas putusan Mahkamah Konstitusi terhadap sistem pemilu legislatif dan presiden 2009 dan 2014.

\section{Metode Penelitian}

Objek Penelitian ini adalah Putusan Mahkamah Konstitusi dalam hal sistem pemilu Legislatif dan Presiden 2009 dan 2014. Penelitian ini adalah penelitian hukum normatif, yang menggunakan bahan hukum primer berupa putusan-putusan Mahkamah Konstitusi, bahan pustaka atau literatur dan peraturan perundang-undangan yang relevan diteliti. Metode penelitian ini akan mengkaji pokok permasalahan melalui pendekatan kasus, yakni mengkaji ratio decidendi dalam putusan-putusan Mahkamah Konstitusi yang menjadi objek penelitian, serta pendekatan perundang-undangan.

\section{Hasil Penelitian dan Pembahasan}

Politik hukum berusaha membuat dan menentukan bagaimana seharusnya manusia bertindak. Politik hukum membuat suatu ius constituendum (hukum yang akan berlaku), dan berusaha agar constituendum itu pada hari kemudian berlaku sebagai ius constitutum (hukum yang akan berlaku di kemudian hari). ${ }^{5}$ Menyambung pandangan Hart, John Austin dengan aliran analytical jurisprudence menyebutkan bahwa satu-satunya sumber hukum adalah kekuasaan tertinggi pada suatu negara. Tata hukum itu nyata dan berlaku karena hukum itu mendapat bentuk positifnya dari institusi yang berwenang, dan hukum itu merupakan wujud perintah penguasa. 6 Sedangkan, pandangan tentang hukum

${ }^{5}$ Bintan Regen Saragih, Politik. Hukum, CV Utomo, Bandung, 2006, hlm. 17.

${ }^{6}$ Bernard L Tanya, dkk, Teori Hukum: Strategi Tertib Manusia Lintas Ruang dan Generasi, Genta Publishing, Yogyakarta, 2010, hlm. 119, dalam Veri Junaidi et.al., Politik. Hukum Sistem Pemilu: Potret Keterbukaan dan Partisipasi Publik dalam Penyusunan Undang-Undang Nomor 8 Tabun 2012 tentang Pemilihan Umum Anggota DPR, DPD, dan DPRD, Yayasan Perludem, Jakarta, hlm. 25. Hans Kelsen menyatakan bahwa hukum bukan saja harus 
dan masyarakat muncul dari Mazhab Sosiological Jurisprudence dengan tokohnya Eugen Ehrlich dan Roscoe Pound. Hukum itu merupakan hubungan antarmanusia. Mazhab ini sangat menghargai pentingnya peranan masyarakat dalam pembentukan hukum. ${ }^{7}$

Sedangkan tugas dari politik hukum itu sendiri ialah untuk meneliti perubahan-perubahan mana yang perlu diadakan terhadap hukum yang ada agar memenuhi kebutuhan-kebutuhan baru di dalam kehidupan masyarakat. Adanya politik hukum menunjukkan eksistensi hukum negara tertentu, begitu pula sebaliknya, eksistensi hukum menunjukkan eksistensi politik hukum dari negara tertentu. Sifat dari politik hukum bisa dibagi menjadi dua: ${ }^{8}$ 1) Politik hukum yang bersifat permanen, bisa juga disebut politik hukum jangka panjang. Misalnya pemberlakuan prinsip pengujian yudisial, ekonomi kerakyatan, keseimbangan antara kepastian hukum, keadilan dan kemanfaatan, penggantian hukum-hukum peninggalan kolonial dengan hukum-hukum nasional, penguasaan sumber daya alam oleh negara, kemerdekaan kekuasaan kehakiman dan sebagainya. Disini terlihat bahwa beberapa prinsip yang dimuat di dalam UUD sekaligus berlaku sebagai politik hukum. 2) Politik hukum yang bersifat periodik, adalah politik hukum yang dibuat sesuai dengan perkembangan situasi yang dihadapi pada setiap periode tertentu baik yang akan memberlakukan maupun yang akan mencabut, misalnya, pada periode 1973-1978 ada politik hukum untuk melakukan kodifikasi yang unifikasi dalam bidang-bidang hukum tertentu, pada periode 1983-1988 ada politik hukum untuk membentuk Peradilan Tata Usaha Negara, dan pada periode 2004-2009 ada lebih dari 250 rencana pembuatan UU yang dicantumkan di dalam Program Legislasi Nasional (Prolegnas).

\footnotetext{
dibersihkan dari anasir-anasir moral, melainkan juga dari anasir-anasir sosiologi, politik, dan sebagainya. Kelsen mencoba memisahkan antara hukum dan moralitas, serta memisahkan antara hukum dan fakta, bisa juga dilihat dalam Jimly Asshiddiqie dan Ali Safa'at, Teori Hans Kelsen Tentang Hukum. Jakarta, Konpres, 2012, hlm. 9-10. Inilah yang kemudian dikenal dengan Teori Murni tentang Hukum (Reine Rechst/The Pure Theory of Law).

${ }^{7}$ Veri Junaidi et.al., Junaidi, Politik Hukum Sistem Pemilu: Potret Keterbukaan dan Partisipasi Publik dalam Penyusunan Undang-Undang Nomor 8 Tahun 2012 tentang Pemilih an Umum Anggota DPR, DPD, dan DPRD, Jakarta, Yayasan Perludem, hlm. 27.

${ }^{8}$ Moh Mahfud MD, Politik Hukum di Indonesia..., Op. Cit, hlm. 3.
} 
Analisis Putusan Mahkamah Konstitusi

Analisis putusan yang diteliti berupa arah politik hukum MK dan implikasinya adalah sebagai berikut. Putusan Mahkamah Konstitusi untuk Pemilu 2009:

\section{Putusan Mahkamah Konstitusi Nomor 22-24/PUU/VI/2008}

\section{Arah Politik Hukum Putusan Mahkamah Konstitusi}

MK mengabulkan permohonan pemohon untuk sebagian, dan menyatakan Pasal 214 UU 10 Tahun 2008 yang merupakan ius constitutum tersebut bertentangan dengan UUD 1945 dan tidak mempunyai kekuatan hukum mengikat. Titik tolak yang dilakukan MK adalah ketentuan Pasal 214 huruf a, huruf b, huruf c, huruf d, dan huruf e UU 10 Tahun 2008 yang menentukan bahwa calon terpilih adalah calon yang mendapat di atas 30\% (tiga puluh per seratus) dari BPP, atau menempati nomor urut lebih kecil, jika tidak ada yang memperoleh 30\% (tiga puluh per seratus) dari BPP, atau yang menempati nomor urut lebih kecil jika yang memperoleh 30\% (tiga puluh per seratus) dari BPP lebih dari jumlah kursi proporsional yang diperoleh suatu partai politik peserta Pemilu adalah inkonstitusional karena bertentangan dengan makna substantif kedaulatan rakyat dan dikualifisir bertentangan dengan prinsip keadilan sebagaimana diatur dalam Pasal 28D ayat (1) UUD 1945. Hal tersebut merupakan pelanggaran atas kedaulatan rakyat jika kehendak rakyat yang tergambar dari pilihan mereka tidak diindahkan dalam penetapan anggota legislatif akan benar-benar melanggar kedaulatan rakyat dan keadilan, jika ada dua orang calon yang mendapatkan suara yang jauh berbeda secara ekstrem terpaksa calon yang mendapat suara banyak dikalahkan oleh calon yang mendapat suara kecil, karena yang mendapat suara kecil nomor urutnya lebih kecil. ${ }^{9}$

Mahkamah lebih mengambil arah politik hukum dalam putusan ini pada aturan penyelenggaraan pelaksanaan sistem suara terbanyak dan membatalkan regulasi sistem nomor urut. Dikarenakan mahkamah memandang harus ada suatu kesetaraan dengan adanya pengakuan terhadap kesamaan kedudukan hukum dan kesempatan yang sama dalam pemerintahan (equality and opportunity 
before the law) sebagaimana diadopsi dalam Pasal 27 ayat (1) dan Pasal 28D ayat (3) UUD 1945, artinya setiap calon anggota legislatif mempunyai kedudukan dan kesempatan yang sama di hadapan hukum, memberlakukan suatu ketentuan hukum yang tidak sama atas dua keadaan yang sama adalah sama tidak adilnya dengan memberlakukan suatu ketentuan hukum yang sama atas dua keadaan yang tidak sama.

\section{Implikasi Putusan Mahkamah Konstitusi}

Putusan Mahkamah Konstitusi memberikan implikasi langsung berupa: (1) Penentuan Kursi Berdasarkan Suara Terbanyak. Putusan ini berimplikasi pada berubahnya sistem dari nomor urut ke dalam suara terbanyak. Bahwa dasar filosofi dari setiap pemilihan atas orang untuk menentukan pemenang adalah berdasarkan suara terbanyak, maka penentuan calon terpilih harus pula didasarkan pada siapapun calon anggota legislatif yang mendapat suara terbanyak secara berurutan, dan bukan atas dasar nomor urut terkecil yang telah ditetapkan. (2) Tidak Menggunakan lagi Standar Ganda. Implikasi putusan ini bisa dikatakan bahwa setiap pemilihan tidak lagi menggunakan standar ganda, yaitu menggunakan nomor urut dan perolehan suara masing-masing Caleg. Mahkamah Konstitusi juga mendalilkan dalam argumentasinya bahwa menurut Mahkamah, ketentuan Pasal 214 UU No. 10 Tahun 2008 mengandung standar ganda sehingga dapat dinilai memberlakukan hukum yang berbeda terhadap keadaan yang sama sehingga dinilai tidak adil.

Adapun implikasi yang tidak langsung, berupa: 1) Multi Tafsir Maksud Suara Terbanyak. Dalam putusan Mahkamah Konstitusi sama sekali tidak disebut "suara terbanyak". Istilah tersebut ditemukan pada pertimbangan hukum Mahkamah Konstitusi. Apa maksud suara terbanyak, apakah suara terbanyak dalam arti mayoritas (jumlah perolehan suara pemenang melebihi kombinasi jumlah perolehan suara calon lain) atau pluralitas (jumlah perolehan suara pemenang melebihi jumlah suara tiap calon) atau apakah penetapan calon terpilih berdasarkan suara terbanyak (mayoritas dan pluralitas) atau menurut urutan perolehan suara terbanyak.10 2) Affirmative Action yang Berkurang. Sistem

${ }^{10}$ Ramlan Surbakti, "Perlu Perpu Atur Suara Terbanyak", dalam Kompas, edisi 11 Februari 2009. 
proporsional terbuka murni menghasilkan partisipasi perempuan di DPR lebih banyak dari sistem proporsional terbuka terbatas. Perumusan ketentuan dalam ketiga pasal tersebut merupakan tindakan afirmatif bagi keterwakilan perempuan yang merupakan desain "dari hulu ke hilir", dalam arti mengkombinasikan antara proteksi dalam mekanisme internal partai (pencalonan dan penempatan dalam daftar calon), dan mekanisme eksternal partai berupa dukungan konstituen yang diraih calon anggota dewan (DPR dan DPRD) melalui perjuangan di daerah pemilihan yang bersangkutan.

\section{Putusan Mahkamah Konstitusi Nomor 09/PUU-VII/2009}

\section{Arah Politik Hukum Putusan Mahkamah Konstitusi}

Memahami konteks partisipasi dalam pemilu, wujud dari partisipasi tersebut salah satunya diwujudkan dengan akses publik berupa eksploratif dalam menyebarkan informasi secara terbuka. Peran serta masyarakat dalam pemilu merupakan pengejawantahan partisipasi masyarakat dalam politik. Partisipasi tersebut merupakan elemen dasar dalam pembentukan pemerintahan yang demokratis. Selain itu, partisipasi masyarakat dalam politik ini merupakan status aktif yang dimiliki oleh warga negara.

Jaminan konstitusional bagi masyarakat untuk berpartisipasi dan hak berpolitik ditegaskan dalam Pasal 28E UUD 1945 ayat (3)“ Setiap orang berhak atas kebebasan berserikat, berkumpul, dan mengeluarkan pendapat. Selanjutnya diatur juga dalam Pasal 28F UUD 1945 yang menegaskan bahwa "Setiap orang berhak untuk berkomunikasi dan memperoleh informasi untuk mengembangkan pribadi dan lingkungan sosialnya, serta berhak untuk mencari, memperoleh, memiliki, menyimpan, mengolah, dan menyampaikan informasi dengan menggunakan segala jenis saluran yang tersedia".

Hal ini menjadikan Mahkamah Konstitusi mempunyai arah penekanan dalam memutus putusan yang berkaitan dengan quick count. Maka dari itu, posisi partisipasi ini menjadi sangat diperlukan dalam proses politik. Civil society yang kuat akan mendorong negara untuk memperkuat dirinya agar terjadi balance of power, sehingga terjadi keseimbangan kekuasaan yang bermuara pada terjadinya checks and balances dalam proses penyelenggaraan negara. Sebagai bentuk 
pengakuan kedaulatan rakyat, maka segala keputusan negara sejauh mungkin harus melibatkan rakyat dalam proses pengambilan keputusan baik melalui wakil rakyat yang berada di parlemen maupun melalui organisasi masyarakat sipil dan pengimbang kekuasaan dalam negara. ${ }^{11}$

Sehingga arah politik hukum yang dikeluarkan oleh MK pada putusan tersebut adalah menyelenggarakan aturan pelaksanaan sistem quick count dan membatalkan larangan quick count. Perbaikan aturan yang dilakukan oleh MK berkaitan dengan ius contituendum Mahkamah juga mempunyai arah agar putusan ini lebih diarahkan kepada pembebasan terkait hasil survei. Tidak ada lagi pembatasan waktu.

\section{Implikasi Putusan Mahkamah Konstitusi}

Implikasi langsung dengan dikeluarkannya Putusan MK No. 9/PUUVII/2009 berupa diperbolehkannya lembaga survei melakukan survei pada masa tenang dan memperbolehkan pengumuman secara bebas perhitungan secara cepat pada hari pemilu atau tanggal 9 April 2009. Dengan demikian, lembaga survei dibebaskan dan diperbolehkan melakukan survei pada hari tenang dan mengumumkan perhitungan secara cepat perolehan suara pemilu pada hari pelaksanaan pemilu.

Putusan ini juga memberikan implikasi tidak langsung berupa: a) Informasi hasil perolehan suara akan lebih cepat. Dalam hak asasi manusia juga dicantumkan bahwa hak masyarakat untuk tahu (rights to know) merupakan bagian dari hak asasi manusia (HAM), yaitu kebebasan untuk mendapatkan informasi dan secara a contrario juga kebebasan untuk memberikan atau menyampaikan informasi (freedom of information). Oleh karena itu, dampak dari putusan ini adalah akan menghasilkan hasil survei yang lebih cepat. ${ }^{12}$ b) Bermunculannya lembaga-lembaga

${ }^{11}$ Rina Yuli Astuti, "Implikasi Putusan MK atas Judicial Review UU No. 10 tahun 2008 Pasal 245 terkait Larangan Survei, Jajak Pendapat dan Quick Count Pada Hari Tenang dan Pelaksanaan Pemilu”, Jurnal Konstitusi, Universitas Muhammadiyah Magelang, Vol 2 No 1 Juni 2009, hlm. 52.

12 Dalam Putusan MK Nomor 22-24/PUU/VI/2008 Mahkamah mendalilkan bahwa sejak awal sudah diketahui oleh umum (notoir feiten) bahwa quick count bukanlah hasil resmi sehingga tidak dapat disikapi sebagai hasil resmi, namun masyarakat berhak mengetahui. Bahkan banyak warga masyarakat yang menunggu hasil quick count tersebut begitu pemungutan suara selesai dilakukan dengan kesadaran penuh bahwa hasil yang resmi dan berlaku adalah hasil yang akan diumumkan kemudian oleh Komisi Pemilihan Umum (KPU) sesuai dengan jadwal resmi yang ditentukan. Oleh sebab itu, baik pengumuman hasil survei pada masa tenang menjelang Pemilu maupun pengumuman hasil quick count begitu selesai pemungutan suara adalah sesuai dengan hak konstitusional bahkan sejalan dengan ketentuan Pasal 28F UUD 1945. 
survei. Putusan ini menjadi pemicu munculnya lembaga-lembaga survei yang dimotori oleh lembaga-lembaga swasta, baik itu yang didukung oleh partai atau pun non partai. Hal ini tidak dapat dipungkiri karena konstelasi persaingan pada saat pemilu dalam tensi yang tinggi. c) Eksistensi lembaga survei yang semakin besar. Eksistensi lembaga survei memiliki peran besar dalam memberikan informasi yang transparan pada proses penghitungan cepat hasil perolehan suara pemilu. Sisi yang lain tanpa koridor yang jelas membuat pemilu akan terancam terganggu dan publik dapat dirugikan atas informasi yang keliru.

\section{Putusan Mahkamah Konstitusi Nomor 102/PUU-VII/2009.}

\section{Arah Politik Hukum Putusan Mahkamah Konstitusi}

Dalam hal ini para Pemohon mendalilkan bahwa dirinya kehilangan haknya untuk memilih pada Pemilu DPR, DPD, dan DPRD 2009 karena tidak terdaftar dalam DPT. Pemohon sama sekali tidak mendapatkan informasi sosialisasi yang memadai tentang DPT dan telah berusaha sedemikian rupa untuk berpartisipasi dalam Pemilu dengan memeriksa DPT dan undangan pada alamat lama para Pemohon pada Pemilu 2004, namun belum memperoleh informasi dan undangan untuk memilih di TPS. Berdasarkan fakta hukum di atas yang dihubungkan dengan kondisi saat ini dalam menyongsong Pemilu Presiden dan Wakil Presiden, maka pertanyaan hukum utama yang harus dijawab oleh Mahkamah adalah apakah Pasal 28 dan Pasal 111 UU No. 42 Tahun 2008 konstitusional atau inkonstitusional dalam hubungannya dengan penyelenggaraan pemilihan umum yang berlaku di Indonesia. ${ }^{13}$

Dalam permasalahan ini, ternyata masih terdapat warga yang masih belum memiliki KTP. Hal itu tentu menjadi tanggungjawab bersama antara KPU sebagai lembaga penyelenggara pemilu dan warga untuk mewujudkan demokrasi. Sebenarnya sebelum pemilu presiden dilaksanakan, KPU mengadakan perbaikan DPT, seharusnya hal itu memanfaatkan perbaikan DPT. Di sini dibutuhkan kesadaran warga atas hak dan kewajiban politiknya dalam rangka mewujudkan demokrasi. Dalam hal ini KTP selain sebagai alat bukti kewarganegaraan juga 
digunakan sebagai sarana penyalur hak pilihnya dalam kehidupan berdemokrasi. ${ }^{14}$

Mahkamah Konstitusi dalam konteks pengawalan demokrasi yaitu Putusan yang menerobos kebuntuan hukum UU Pilpres terkait dengan permasalahan calon pemilih yang tidak terdaftar di dalam Daftar Pemilih Tetap (DPT). Dengan merujuk Putusan Nomor 011-017/PUU-I/2003 bertanggal 24 Februari 2004, Mahkamah Konstitusi menegaskan bahwa hak konstitusional warga negara untuk memilih dan dipilih (rights to vote and right to be candidate) adalah hak yang dijamin oleh konstitusi, undang-undang, dan konvensi internasional, sehingga pembatasan, penyimpangan, peniadaan, dan penghapusan akan hak dimaksud merupakan pelanggaran terhadap hak asasi dari warga negara. ${ }^{15}$ Dalam hal ini arah politik hukum MK lebih kepada penyelenggaraan pemilu boleh dilakukan dengan menggunakan KTP atau Passpor dengan beberapa syarat tertentu sesuai dengan putusan Mahkamah.

\section{Implikasi Putusan Mahkamah Konstitusi}

Implikasi langsung dari pelaksanaan putusan Mahkamah Konstitusi No. 102.PUU-VII/2009 tentang penggunaan KTP dan Paspor dalam pemilu presiden dan wakil presiden adalah semakin kuatnya hak warga negara Indonesia sebagai wujud dari Indonesia adalah negara demokrasi dan hukum yang berbunyi "Kedaulatan berada di tangan rakyat dan dilaksanakan menurut Undang-Undang Dasar" dan “Negara Indonesia adalah negara hukum seperti yang tercantum Pasal 1 ayat (2) dan ayat (3) UUD Negara Republik Indonesia Tahun 1945.16 Hak konstitusional warga yang tidak masuk dalam DPT telah hilang pada pemilu legislatif, maka pada pemilu presiden telah dikuatkan berkat putusan MK tersebut.

Putusan Mahkamah Konstitusi juga memberikan implikasi tidak langsung berupa: a) Mengurangi terjadinya perselisihan hasil Pemilihan Umum Presiden. Dalam putusan tersebut hak pilih warga yang menggunakan KTP atau KK ini tak

${ }^{14}$ Sunny Ummul Firdaus dkk, Implementasi Putusan Mahkamah Konstitusi Nomor 102/PUU-VII/2009 tentang Penggunaan KTP dan Paspor dalam Pemilu Presiden dan Wakil Presiden di Kota Surakarta, dalam Penelitian Mabkamah Konstitusi Republik Indonesia berkerjasama dengan Pusat Penelitian dan Pegembangan Konstitusi dan Hak. Asasi Manusia Universitas Sebelas Maret, Surakarta, 2010, hlm. 55.

${ }^{15}$ Ibid., hlm. 47.

16 Ibid., hlm. 56. 
berlaku di semua TPS. ${ }^{17}$ MK menilai selama ini masalah DPT sering disengketakan, padahal DPT bukanlah masalah yang berdiri sendiri melainkan ada kaitannya dengan pengelolaan kependudukan di masing masing daerah. Maka, dengan Putusan ini setidaknya dapat mengurangi terjadinya perselisihan hasil Pemilihan Umum Presiden antar peserta pemilu presiden. ${ }^{18}$ b) KPU bekerja ekstra. Setelah dibacakan putusan MK tersebut KPU akan bertindak ekstra, mengingat pelaksanaan pemungutan suara tinggal dua hari, sehingga KPU harus memaksimalkan waktu dua hari tersebut untuk menjaga profesionalitas KPU. ${ }^{19}$

\section{Analisis Putusan Mahkamah Konstitusi untuk Pemilu Tahun 2014}

\section{Putusan Mahkamah Konstitusi Nomor 51, 52, 54, 55/PUU-X/2012}

\section{Arah Politik Hukum Putusan Mahkamah Konstitusi}

Ius constitutum yang diputus pada perkara ini meliputi beberapa pasal yang terdapat dalam UU Nomor 8 Tahun 2012. Pasal 8 ayat (1) UU No. 8 Tahun 2012, tidak memenuhi asas keadilan bagi partai politik lama karena pada saat verifikasi untuk menjadi peserta Pemilihan Umum 2009, semua persyaratan administrasi sudah dipenuhi oleh semua partai politik peserta Pemilihan Umum 2009, sehingga tidak tepat jika partai politik yang pada Pemilihan Umum 2009 telah dinyatakan memenuhi persyaratan, namun pada pemilihan umum berikutnya diwajibkan memenuhi syarat ambang batas perolehan suara, atau jika partai politik bersangkutan tidak memenuhi ambang batas, diwajibkan memenuhi persyaratan yang berbeda dengan partai politik peserta Pemilihan Umum 2009.

Titik tolak ketentuan yang demikian, menurut Mahkamah, tidak memenuhi prinsip keadilan karena memberlakukan syarat-syarat berbeda bagi pihak-pihak yang mengikuti suatu kontestasi yang sama. Menurut Mahkamah, dipenuhinya ambang batas perolehan suara pada Pemilihan Umum 2009 tidak dapat dijadikan sebagai satu-satunya ketentuan mengenai syarat atau kriteria dalam keikutsertaan partai politik lama sebagai peserta Pemilihan Umum 2014. ${ }^{20}$

${ }_{17}$ Surabayakita.com, dalam Coblos Pemilu 2014 Boleh Pakai KTP.

18 Sunny Ummul Firdaus dkk, Implementasi Putusan Mahkamah..., Op.Cit, hlm. 56.

${ }^{19}$ Ibid., hlm. 57.

20 Ketidakadilan juga terdapat pada Penjelasan Pasal 8 ayat (1) UU 8/2012. Hal yang terakhir ini didasarkan pada pertimbangan bahwa tidak ada penjelasan dari suatu pasal yang dapat berdiri sendiri, sehingga Penjelasan Pasal 8 ayat (1) UU 8 Tahun 2012 harus mengikuti putusan mengenai pasal yang dijelaskannya. 
Kemudian untuk pengujian konstitusional pada Pasal 8 ayat (2) Mahkamah menimbang, Pasal 8 ayat (2), UU No. 8 Tahun 2012 menentukan bahwa partai politik yang tidak memenuhi ambang batas perolehan suara pada pemilihan umum sebelumnya dan partai politik baru untuk menjadi peserta pemilihan umum harus memenuhi persyaratan tertentu. Setelah mempersandingkan Pasal 8 UU No. 10 Tahun 2008 dengan Pasal 8 UU No. 8 Tahun 2012 mengenai persyaratan partai politik menjadi peserta pemilihan umum.

MK juga menyimpulkan bahwa lembaga legislatif dapat menentukan ambang batas sebagai legal policy bagi eksistensi Partai Politik baik berbentuk ET maupun PT. Kebijakan seperti ini diperbolehkan oleh konstitusi sebagai politik penyederhanaan kepartaian karena pada hakikatnya adanya Undang-Undang tentang Sistem Kepartaian atau Undang-Undang Politik yang terkait memang dimaksudkan untuk membuat pembatasan-pembatasan sebatas yang dibenarkan oleh konstitusi. Mengenai berapa besarnya angka ambang batas adalah menjadi kewenangan pembentuk undang-undang untuk menentukannya tanpa boleh dicampuri oleh Mahkamah selama tidak bertentangan dengan hak politik, kedaulatan rakyat, dan rasionalitas.

Hal ini menjadi tolok ukur bahwa arah politik hukum MK dalam memutus perkara ini lebih kepada pelaksanaan sistem persamaan dalam verifikasi parpol, penghapusan diskriminasi parpol lama dan baru serta pemberlakuan PT 3,5\%. Karena dampak yang ditimbulkan jika MK tidak memberlakukan sama antar partai baru dan partai lama adalah penyimpangan dalam bentuk prosedural. Putusan MK pada perkara ini adalah mengabulkan untuk sebagian. Melihat dasar argumentasi hakim dalam memutus perkara ini bisa teliti bahwa MK memiliki arah politik hukum dari putusan ini adalah penyelenggaraan pelaksanaan sistem persamaan dalam verifikasi parpol, penghapusan diskriminasi parpol lama dan baru dan pemberlakuan PT 3,5\%.

\section{Implikasi Putusan MK}

Hasil putusan MK ini berimplikasi bahwa semua partai politik harus diberlakukan persyaratan yang sama untuk satu kontestasi politik atau pemilihan umum yang sama. Dan Partai Politik yang tidak memenuhi ambang batas perolehan suara sekurang-kurangnya 3,5\% (tiga koma lima persen) dari jumlah 
suara nasional, maka tidak mendapatkan perolehan kursi di DPR saja, tidak berimbas pada perolehan kursi anggota di DPRD provinsi dan DPRD Kabupaten/Kota.

Putusan MK juga memberikan implikasi tidak langsung, yakni banyak suara yang hangus terbuang akibat penerapan parliamentary threshold (dalam putusan ini terutama pada suara nasional). Sistem parliamentary threshold juga menimbulkan kontra. Sistem parliamentary threshold selain menghilangkan keaslian suara pemilih, juga bisa mengancam integrasi bangsa. Penerapan parliamentary threshold dinilai beberapa pihak bisa memasung proses demokrasi yang baru berlangsung sejak reformasi 1998. ${ }^{21}$

\section{Putusan Mahkamah Konstitusi Nomor 14/PUU-XI/2013.}

\section{Arah Politik Hukum Putusan Mahkamah Konstitusi}

Pasal-pasal diajukan pemohon menurut MK tidak sesuai dengan original intent Pasal 22E ayat (2) serta tidak sejalan dengan Pasal 6A UUD 1945. Titik tolak hakim-hakim Mahkamah melihat dari aspek efisiensi baik pembiayaan dan waktu. Penyelenggaraan Pilpres dan Pemilu Anggota Lembaga Perwakilan secara serentak memang akan lebih efisien, sehingga pembiayaan penyelenggaraan lebih menghemat uang negara yang berasal dari pembayar pajak dan hasil eksploitasi sumber daya alam serta sumber daya ekonomi lainnya. Hal itu akan meningkatkan kemampuan negara untuk mencapai tujuan negara sebagaimana diamanatkan dalam Pembukaan UUD 1945 yang antara lain untuk memajukan kesejahteraan umum dan sebesar-besarnya kemakmuran rakyat. Selain itu, Pilpres yang diselenggarakan secara serentak dengan Pemilu Anggota Lembaga Perwakilan juga akan mengurangi pemborosan waktu dan mengurangi konflik atau gesekan horizontal di masyarakat. Inilah yang yang melandasi MK memutus pemilu menjadi serentak.

Pengalaman yang telah berjalan adalah Pilpres dilaksanakan setelah Pemilu Anggota Lembaga Perwakilan, karena Presiden dan/atau Wakil Presiden dilantik oleh MPR [Pasal 3 ayat (2) UUD 1945], sehingga Pemilu DPR dan DPD didahulukan

21 Sunny Ummul Firdaus, "Relevansi Parliamentary Threshold terhadap Pelaksanaan Pemilu yang Demokratis,” Jurnal Konstitusi: Implikasi Putusan MK terhadap Sistem Pemilu dan Demokrasi. 8, No. 2 Maret 2011, hlm. 94. 
untuk dapat dibentuk MPR. Lembaga inilah yang kemudian melantik Presiden dan Wakil Presiden, oleh karenanya harus dibentuk lebih dahulu. ${ }^{22}$

Putusan pada perkara ini MK memutuskan untuk mengabulkan untuk sebagian dan menunda pemberlakuannya. Penyelenggaraan aturan pelaksanaan sistem pemilu legislatif dan pilpres serentak dan membatalkan regulasi sistem pemilu legislatif dan pilpres yang terpisah. MK memutus berdasarkan original intent dari konstitusi. Sebagaimana yang telah disebutkan bahwa Pasal 22E UUD 1945 ayat (2) Pemilihan umum diselenggarakan untuk memilih anggota Dewan Perwakilan Rakyat, Dewan Perwakilan Daerah, Presiden dan wakil presiden dan Dewan Perwakilan Rakyat Daerah. Serta pada Pasal 6A UUD 1945. Maka penafsiran Hakim MK langsung tertuju pada original intent dari Pasal 22E tersebut serta Pasal 6A.

Putusan demikian dihasilkan meski telah diketahui bahwa original intent Pasal 22E ayat (2) UUD 1945 memang menentukan agar pemilihan umum diselenggarakan untuk memilih anggota Dewan Perwakilan Rakyat, Dewan Perwakilan Daerah, Presiden dan Wakil Presiden dan Dewan Perwakilan Rakyat Daerah "bersama-sama atau serentak". Mahkamah kala itu menyadari, metode penafsiran original intent bukanlah segala-galanya. ${ }^{23}$

\section{Implikasi Putusan MK}

Putusan MK meberikan implikasi langsung berupa: a) Sistem pemilu legislatif dan pilpres berubah menjadi serentak, implikasi langsung akibat putusan tersebut adalah pemilu legislatif dan pilpres diselenggarakan secara serentak. Secara teoritik, terdapat dua akibat hukum lanjutannya yang bisa diidentifikasi, pertama, akibat hukum pra Pemilu Presiden dan Wakil Presiden, adalah gugatan terhadap keputusan-keputusan KPU meliputi: penetapan tahapan Pilpres, penetapan pasangan calon, dan pengadaan barang dan jasa, kedua, akibat hukum pasca Pilpres adalah gugatan terhadap keabsahan Presiden dan Wakil Presiden terpilih. Semua gugatan akan dialamatkan ke Pengadilan Tata Usaha Negara di Jakarta, karena locusnya ada di Jakarta. ${ }^{24}$ b) Melanggar Pasal 47 UU No. 24 Tahun 2003 tentang Mahkamah Konstitusi. Dalam Pasal 47 UU No. 24 Tahun 2003 tentang

22 Lihat dalam dissenting opinion Hakim Maria Farida Indrati dalam putusan MK Nomor 14/PUU$\mathrm{XI} / 2013$.

${ }^{23}$ Ibid.

${ }^{24}$ http://pjminews.com/index.php?page=artikel\&id=368, diakses 4 Oktober 2014. 
Mahkamah Konstitusi ditegaskan: Putusan Mahkamah Konstitusi memperoleh kekuatan hukum tetap sejak selesai diucapkan dalam sidang pleno terbuka untuk umum. Maka ketentuan hukumnya Pasal 112 UU No. 42 Tahun 2008 tentang pemilihan presiden dan wakil presiden yang dinyatakan MK bertentangan bertentangan dengan UUD 1945, berlaku positif sejak putusan MK dibacakan. Sehingga Pasal 112 tidak lagi mempunyai kekuatan hukum mengikat. Hal ini menjadikan putusan MK memiliki sifat bersyarat dan mudah mengabaikan regulasi yang telah diamanat dalam UUD 1945 yang telah diatribusikan ke dalam UU No. 24 Tahun 2003 tentang Mahkamah Konstitusi. c) Berseberangan dengan Putusan yang terdahulu (Putusan Nomor 51-52-59/PUU-VI/2008). Meskipun negara Indonesia tidak menganut putusan hakim yang tidak tertumpu pada putusan sebelumnya, tetapi dalam putusan ini terlihat jelas kontradiktif antara putusan ini dengan Putusan Nomor 51-52-59/PUU-VI/2008, bertanggal 18 Februari 2009, padahal objek kajiannya sama. Hal ini menandakan dasar argumentasi hakim pada putusan terdahulu berbeda dengan dasar argumentasi hakim dalam putusan ini. Sudut pandang hakim dalam memahami putusan pun berbeda-beda.

Adapun implikasi tidak langsung dari Putusan MK tersebut berupa: a) Penundaan Penerapan Putusan untuk Pemilu 2014. Menyadari akibat hukum yang fundamental itu, maka MK menyiasatinya dengan menyatakan, amar putusan tersebut di atas berlaku untuk penyelenggaraan pemilihan umum 2019 dan pemilihan umum seterusnya. b) Penerapan Sistem Presidential Threshold yang Ambigu dan Tidak Pada Tempatnya, dengan pemilu yang serentak maka partai tidak bisa mencalonkan Capres dan Cawapresnya, karena pemilu dilakukan secara serentak. Maka harus menggunakan presidential threshold di pemilu sebelumnya. Hal ini menjadi permasalahan karena seharusnya dilakukan dalam pemilu yang sama, bukan pemilu sebelumnya. ${ }^{25}$

\section{Putusan Mahkamah Konstitusi Nomor 24/PUU-XII/2014}

\section{Arah Politik Hukum Putusan Mahkamah Konstitusi}

Ius constitutum yang ada pada putusan MK ini adalah menyatakan Pasal 247 ayat (2), ayat (5), dan ayat (6), Pasal 291, serta Pasal 317 ayat (1) dan ayat (2)

\footnotetext{
${ }^{25} \mathrm{http://piminews.com/index.php?page=artikel \& id=368,} \mathrm{diakses} 4$ Oktober 2014.
} 
UU No. 8 Tahun 2012 tentang Pemilihan Umum Anggota Dewan Perwakilan Rakyat, Dewan Perwakilan Daerah, Dewan Perwakilan Rakyat Daerah bertentangan dengan Undang-Undang Dasar Negara Republik Indonesia Tahun 1945 dan tidak mempunyai kekuatan hukum mengikat.

Sebagaimana dasar argumentasi hakim dalam memutus perkara, titik tolak yang ada dalam putusan MK ini sekaligus sebagai ius constituendum, Mahkamah berpendapat bahwa jajak pendapat atau survei maupun penghitungan cepat (quick count) hasil pemungutan suara dengan menggunakan metode ilmiah adalah suatu bentuk pendidikan, pengawasan, dan penyeimbang dalam proses penyelenggaran negara termasuk pemilihan umum. Sejauh dilakukan sesuai dengan prinsip metodologis ilmiah dan tidak bertendensi memengaruhi pemilih pada masa tenang maka pengumuman hasil survei tidak dapat dilarang. Bahwa sejak awal sudah diketahui oleh umum (notoir feiten) bahwa quick count bukanlah hasil resmi sehingga tidak dapat disikapi sebagai hasil resmi, namun masyarakat berhak mengetahui. Maka dari itu qiuck count sejalan dengan ketentuan Pasal 28F UUD 1945.

Pasal 28F UUD 1945 secara tegas menyatakan,'Setiap orang berhak untuk berkomunikasi dan memperoleh informasi untuk mengembangkan pribadi dan lingkungan sosialnya, serta berhak untuk mencari, memperoleh, memiliki, menyimpan, mengolah, dan menyampaikan informasi dengan menggunakan segala jenis saluran yang tersedia. ${ }^{26}$

MK menginginkan tidak adanya pembatasan waktu dalam menetapkan quick count sehingga dalam masyarakat bisa mengetahui hasil secara cepat tanpa ada pembatasan. Selain itu putusan mengenai hal yang sama pernah dilakukan dua kali berarti sudah tiga kali MK memutus perkara yang sama. Dan kesemuanya itu memutus dengan dasar argumentasi yang hampir sama. PasalPasal dalam UU No. 10 Tahun 2008 yang berkaitan dengan quick count pernah diujikan dan dikabulkan. Kemudian DPR membuat lagi UU yang baru untuk pemilu tahun 2014 yaitu UU No. 8 Tahun 2012, isi materi tentang quick count yang ada pada UU tersebut masih mencantumkan jangkan waktu pembatasan dalam menetapkan hitung cepat. Kemudian UU tersebut terkait quick count diujikan dan

${ }^{26}$ Lihat Putusan Nomor 9/PUU-VII/2009. 
dikabulkan oleh MK. Selain itu terdapat juga aturan qiuck count pada UU No. 42 Tahun 2008 yang kembali di uji materilkan dan kembali dikabulkan oleh MK. Maka, ius constituendum dari putusan ini adalah menginginkan tidak adanya pembatasan waktu dalam menetapkan quick count sehingga dalam masyarakat bisa mengetahui hasil secara cepat tanpa ada pembatasan.

Sehingga MK mempunyai dasar bahwa perkara ini merupakan perkara mutatis dan mutandis, maka MK mempunyai arah politik hukum dalam Putusan Mahkamah Konstitusi Nomor 24/PUU-XII/2014 lebih kepada keinginan melaksanakan putusannya secara sama. MK juga menerima dasar argumentasi para pemohon ketika mengambil yurisprudensi dengan putusan MK (Nomor 09/PUUVII/2009, 30 Maret 2009) dan Putusan MK (Nomor 98/PUU-VII/2009, 3 Juli 2009). Peneliti menganggap bahwa putusan ini mempunyai unsur putusan yang mengacu pada putusan sebelumnya, meskipun secara yuridis MK mempunyai dasar argumen tersendiri dalam memutus. Dan bukan memutus dengan dasar argumen sudah pernah terjadi putusan yang sama sebelumnya. Sehingga bisa ditarik kesimpulan bahwa arah politik hukum Mahkamah Konstitusi dalam perkara ini adalah pelaksanaan aturan sistem quick qount dan membatalkan regulasi sistem larangan quick qount serta menghilangkan pembatasan waktu.

\section{Implikasi Putusan MK}

Putusan MK berimplikasi pada berubahnya regulasi quick count dan membatalkan larangan quick count pada jangka waktu yang telah yang ditetapkan UU. Sehingga Pasal 247 ayat (2), ayat (5), dan ayat (6), Pasal 291, serta Pasal 317 ayat (1) dan ayat (2) UU No. 8 Tahun 2012 tentang Pemilihan Umum Anggota Dewan Perwakilan Rakyat, Dewan Perwakilan Daerah, Dewan Perwakilan Rakyat Daerah bertentangan dengan Undang-Undang Dasar Negara Republik Indonesia Tahun 1945 serta tidak memiliki kekuatan hukum mengikat.

Adapun implikasi tidak langsung berupa: a) Informasi hasil perolehan suara akan lebih cepat. Jika melihat konsep dari quick count sendiri, quick count atau hitung cepat hasil pemilu adalah sebuah metode verifikasi hasil pemilu yang dilakukan dengan menghitung prosentase hasil pemilu di TPS-TPS yang 
dijadikan sampel. ${ }^{27}$ Selain itu dengan quick count biaya yang dibutuhkan jauh lebih hemat daripada melakukan penghitungan secara keseluruhan. ${ }^{28}$ b) Bermunculannya lembaga-lembaga survei. Implikasi yang sangat menonjol pasca putusan ini terlebih lagi ketika pemilu 2014 adalah bermunculannya lembaga survei. KPI juga meminta dalam siaran hitung cepat, lembaga survei dan quick count menyampaikan informasi yang lengkap dan akurat terkait sumber dana dan metodologi yang digunakan dalam quick count. c) Eksistensi lembaga survei yang semakin besar. Kehadiran lembaga survei mampu menjadi jembatan dan memberikan informasi tentang persepsi, harapan dan evaluasi publik terhadap kondisi dan perkembangan sosial-politik, bahkan juga bagian dari pendidikan politik. Asal sesuai dengan etika dan profesionalisme sebagai lembaga survei. ${ }^{29}$

\section{Putusan Mahkamah Konstitusi Nomor 50,51,53/PUU-XII/2014.}

\section{Arah Politik Hukum Putusan Mahkamah Konstitusi}

Ius constitum dalam putusan MK pada perkara ini terdapat dalam UU No. 42 Tahun 2008 tentang Pemilihan Presiden dan Wakil Presiden Terkait dengan Pemilihan Umum Satu Putaran. Pasal yang dikabulkan oleh MK adalah Pasal 159 ayat (1) sepanjang tidak dimaknai tidak berlaku untuk pasangan calon Presiden dan wakil Presiden yang hanya terdiri dari dua pasangan calon. Bunyi pasal “Pasangan Calon terpilih adalah Pasangan Calon yang memperoleh suara lebih dari 50\% (lima puluh persen) dari jumlah suara dalam Pemilu Presiden dan Wakil Presiden dengan sedikitnya 20\% (dua puluh persen) suara di setiap provinsi yang tersebar di lebih dari 1/2 (setengah) jumlah provinsi di Indonesia".

Titik tolaknya terdapat dalam putusan MK No. 50/PUU-XII/2014, Mahkamah Konstitusi memberikan makna baru terhadap Pasal 159 ayat (1) UU tentang Pemilu Presiden dan Wapres. Pasal 159 ayat (1) UU Pilpres yang merupakan tindak lanjut dari Pasal 6A ayat (3) UUD 1945 mengatur bahwa pasangan calon terpilih adalah pasangan calon yang memperoleh suara lebih dari 50 persen dari jumlah suara dalam pemilu presiden dan wakil presiden dengan sedikitnya 20 persen suara di setiap provinsi yang tersebar di lebih dari setengah

\footnotetext{
${ }^{27}$ http://www.cyrusnetwork.co/cyrus/home/services, diakses tanggal 28 Oktober 2014.

28 http://www.cyrusnetwork.co/cyrus/home/services, diakses tanggal 28 Oktober 2014.

${ }_{29}$ http://news.detik.com/read/2014/04/08/171548/2549309/103/lembaga-survei-antara-integritaskekuasaan-dan-komersial, diakses tanggal 28 Oktober 2014
} 
jumlah provinsi di Indonesia. ${ }^{30}$ MK telah memberikan makna baru (judicial interpretation) atas ketentuan mengenai syarat keterpilihan pasangan capres melalui putusannya dengan model konstitusional bersyarat, yaitu bahwa syarat sebaran suara tersebut hanya berlaku jika pasangan capres terdiri atas lebih dari dua pasang capres yang berkontestasi dalam pilpres. ${ }^{31}$

Hakim Konstitusi Patrialis Akbar mengatakan, Indonesia merupakan negara hukum yang luas sehingga butuh pemerintahan yang kuat dengan memperoleh dukungan rakyat yang kuat untuk menghindari hegemoni partai politik dalam membangun koalisi permanen. Karena pasangan calon presiden dan wakil presiden dari semula hanya dua pasangan calon, maka pemilihan presiden dan wakil presiden cukup satu putaran saja sebab calonnya tidak berubah. ${ }^{32}$ Menurut Patrialis, dalam penentuan pasangan yang menang tetap dengan menggunakan Pasal 6A ayat (4) UUD 1945. Pemilihan cukup dilakukan satu putaran saja, tetapi cara menghitung perolehan suara yang menjadi dua tahap.

Walaupun diwarnai perbedaan pendapat, pada akhirnya MK mengabulkan untuk menjadikan pemilihan presiden menjadi satu putaran dan memerintahkan keputusan ini untuk segera dimasukkan ke dalam berita negara Republik Indonesia sebagaimana mestinya. ${ }^{33}$ Putusan MK ini tetap sebuah terobosan hukum (legal breakthrough) yang cukup berani sebagai respons atas tuntutan publik dan kebutuhan sistem ketatanegaraan aktual. Arah politik hukum yang ditempuh oleh Mahkamah lebih kepada Penyelenggaraan pelaksanaan sistem pilpres satu putaran dan membatalkan regulasi sistem pilpres dua putaran, sepanjang tidak dimaknai tidak berlaku untuk pasangan calon Presiden dan Wakil Presiden yang hanya terdiri dari dua pasangan calon.

\footnotetext{
${ }^{30}$ W Riawan Tjandra,’Implikasi Putusan MK tentang Pilpres”, dalam Kompas, 10 Juli 2014.

${ }^{31}$ Ibid.

32 Risalah Sidang, Pernyataan Patrialis Akbar dalam sidang di Mahkamah Konstitusi, Jakarta Pusat, Kamis 3 Juli 2014. Jika tidak memenuhi persyaratan sebaran maka dilakukan penghitungan kembali tanpa memperhitungkan sebaran suara, sehingga yang memperoleh suara terbanyak yang dilantik jadi presiden.

33 Sidang pembacaan putusan ini dihadiri oleh hakim konstitusi Hamdan Zoelva, Arief Hidayat, Ahmad Fadlil Sumadi, Maria Farida Indrati, Aswanto, Anwar Usman, Muhammad Alim, Patrialis Akbar, Wahiduddin Adams.
} 


\section{Implikasi Putusan MK}

Implikasi secara langsung akibat putusan tersebut adalah MK dalam putusannya menyatakan Pasal 159 ayat (1) UU No. 42 Tahun 2008 tentang Pemilihan Umum Presiden dan Wakil Presiden tidak bertentangan dengan UUD 1945, sepanjang Pasal 159 ayat (1) UU RI No. 42 Tahun 2008 tidak diberlakukan untuk Pemilu Presiden dan Wakil Presiden dengan dua pasangan Calon Presiden dan Wakil Presiden. Menurut MK, Permohonan yang diajukan oleh koalisi pengacara, advokat dan dosen oleh Muhammad Asrun, Heru Widodo dan kawan-kawan.

Adapun implikasi tidak langsung dari Putusan MK berupa: a) Implikasi Sistem Pemilu Mayoritas. Pertama, dalam varian mayoritas, pasangan capres dinyatakan terpilih cukup berdasarkan persyaratan perolehan suara 50 persen plus satu. ${ }^{34}$ Kedua, melalui putusan MK itu, kini sistem pilpres di Indonesia menggunakan dua model sistem pemilu yang dikaitkan dengan jumlah kontestan pilpres dalam pilpres. Jika kontestan pilpres terdiri atas lebih dari dua pasang capres, tetap digunakan sistem mayoritas mutlak. ${ }^{35}$ b) Implikasi Konstitusionalisme Bersyarat, Judicial interpretation. Bahwa syarat sebaran suara tersebut hanya berlaku jika pasangan capres terdiri atas lebih dari dua pasang capres yang berkontestasi dalam pilpres. ${ }^{36}$ Namun, untuk kali ini putusan MK ini tetap sebuah terobosan hukum (legal breakthrough) yang cukup berani sebagai respons atas tuntutan publik dan kebutuhan sistem ketatanegaraan aktual. ${ }^{37}$ c) Ahistoris dari Pasal 6A Ayat (3) UUD 1945. Pada pasal ini menginginkan mayoritas mutlak, sehingga demokratisasi yang ada akan berjalan secara maksimal dengan adanya sinergitas antara Legislatif dan Eksekutif. Serta persebaran yang menyeluruh di wilayah Indonesia. Tetapi dengan putusan ini akan memungkinkan persebaran yang tidak menyeluruh (minimal 20\%) seperti yang ada pada pasal 6A ayat (3), jika nanti langsung ditentukan dengan suara terbanyak saja. (4) Dukungan Legislatif yang Rendah, implikasi ini muncul jika capres dan cawapres tidak lebih dari dua pasang calon. Sehingga sistem yang digunakan adalah sistem mayoritas

\footnotetext{
${ }^{34}$ W Riawan Tjandra, "Implikasi Putusan MK tentang Pilpres", dalam Kompas, 10 Juli 2014

35 Ibid.

${ }^{36}$ Ibid.

${ }^{37}$ W Riawan Tjandra, Implikasi Putusan MK, Op.,Cit.
} 
sederhana. ${ }^{38}$ Pasal 6A UUD 1945 dengan mengaitkan logika perumus UUD 1945 yang semula berpendirian sistem pilpres dengan varian mayoritas mutlak bersifat ekuivalen dengan banyaknya jumlah parpol yang mengusung pasangan capres. ${ }^{39}$

\section{Penutup}

Politik hukum sistem pemilu dalam putusan-putusan Mahkamah Konstitusi ini secara umum lebih kepada arah penyelenggaraan negara yang berintikan pelaksanaan ketentuan sistem pemilu yang ada, termasuk penegasan aplikasi penerapan pemilu dengan sistem proporsional terbuka agar sesuai dengan substansi demokrasi pemilu. Putusan Mahkamah Konstitusi dalam putusan yang terkait dengan sistem pemilu 2009 dan 2014, secara general sifat putusan MK lebih kepada penegakan untuk mencapai demokrasi substansial sedangkan demokrasi proseduralnya kurang begitu diperhatikan. Sehingga beberapa putusan MK mengabaikan sifat demokrasi prosedural guna mendapatkan demokrasi substansialnya, terutama dalam Undang-Undang Mahkamah Konstitusi itu sendiri.

Kemudian putusan-putusan tersebut mempunyai implikasi yang bermacam-macam terkait dengan sistem pemilu yang ada. Terdapat implikasi secara langsung dan tidak langsung. Di dalam implikasi langsung dan tidak langsung tersebut tidak terlepas dari implikasi yang positif dan negatif untuk kelangsungan sistem pemilu legislatif dan presiden.

\section{Daftar Pustaka}

Asshiddiqie, Jimly dkk., Teori Hans Kelsen Tentang Hukum. Jakarta, Konpres, 2012. Basuki, Udiyo, “Quo Vadis UUD 1945: Refleksi 65 Tahun Indonesia Berkonstitusi", dalam Jurnal Supremasi Hukum, Vol. 1 No. 1, Juni 2012.

http:/ / pjminews.com/index.php?page=artikel\&id=368.

http://www.cyrusnetwork.co/cyrus/home/services

http://news.detik.com/read/2014/04/08/171548/2549309/103/lembaga-surveiantara-integritas-kekuasaan-dan-komersial 
Jazuni, Legislasi Hukum Islam di Indonesia, Citra Aditya Bakti, Bandung, 2005.

Junaidi, Veri et.al, Politik Hukum Sistem Pemilu: Potret Keterbukaan dan Partisipasi Publik dalam Penyusunan Undang-Undang Nomor 8 Tahun 2012 tentang Pemilih an Umum Anggota DPR, DPD, dan DPRD, Jakarta: Yayasan Perludem.

M. Gaffar, Jenedjri, Politik Hukum Pemilu, Konstitusi Press, Jakarta, 2012.

Mahfud MD., Moh., Politik Hukum di Indonesia, PT Rajagrafindo Persada, Jakarta, 2009.

Putusan Mahkamah Konstitusi Nomor 102/PUU-VII/2009

Ramlan Surbakti, "Perlu Perpu Atur Suara Terbanyak", dalam Kompas, edisi 11 Februari 2009.

Regen Saragih, Bintan, Politik Hukum, CV Utomo, Bandung, 2006.

Risalah Sidang, Pernyataan Patrialis Akbar dalam sidang di Mahkamah Konstitusi, Jakarta Pusat, Kamis 3 Juli 2014.

Surabayakita.com, dalam Coblos Pemilu 2014 Boleh Pakai KTP

Tanya, Bernard L, dkk, Teori Hukum: Strategi Tertib Manusia Lintas Ruang dan Generasi, Genta Publishing, Yogyakarta, 2010.

Tjandra, W Riawan, "Implikasi Putusan MK tentang Pilpres", dalam Kompas, 10 Juli 2014

Ummul Firdaus, Sunny dkk, Implementasi Putusan Mahkamah Konstitusi Nomor 102/PUU-VII/2009 tentang Penggunaan KTP dan Paspor dalam Pemilu Presiden dan Wakil Presiden di Kota Surakarta, dalam Penelitian Mahkamah Konstitusi Republik Indonesia berkerjasama dengan Pusat Penelitian dan Pegembangan Konstitusi dan Hak Asasi Manusia Universitas Sebelas Maret, Surakarta, 2010.

Ummul Firdaus, Sunny, "Relevansi Parliamentary Threshold terhadap Pelaksanaan Pemilu yang Demokratis," Jurnal Konstitusi: Implikasi Putusan MK terhadap Sistem Pemilu dan Demokrasi. 8, No. 2 Maret 2011.

W Riawan Tjandra, Implikasi Putusan MK tentang Pilpres, dalam Kompas, 10 Juli 2014

Yuli Astuti, Rina, "Implikasi Putusan Mk atas Judicial Review UU No. 10 Tahun 2008 Pasal 245 Terkait Larangan Survei, Jajak Pendapat dan Quick Count Pada Hari Tenang dan Pelaksanaan Pemilu". Jurnal Konstitusi Universitas Muhammadiyah Magelang, Vol 2 No 1 Juni 2009. 